\title{
Ankara Koșullarında Farklı Dozlarda Azotlu Gübrelemenin Arıotu (Phacelia tanacetifolia Benth.)'nun Ot Verimine ve Kalitesine Etkileri
}

\author{
*Uğur ÖZKAN, Cafer Sırrı SEVIMAY \\ *Ankara Üniversitesi, Ziraat Fakültesi, Tarla Bitkileri Bölümü, Ankara, Türkiye \\ ${ }^{*}$ Corresponding author e-mail (Sorumlu yazar e-posta): ugurozkan@ankara.edu.tr
}

\section{Öz}

Bu araștırma 2013-2014 yıllarında Ankara Üniversitesi, Ziraat Fakültesi, Tarla Bitkileri Bölümü deneme tarlalarında, arıotu (Phacelia tanacetifolia Benth.) bitkisinin farklı azotlu gübre dozları altında ot veriminde ve kalitesinde meydana gelen değișimleri incelemek amacıyla yürütülmüștür. Araștırma tesadüf bloklarında bölünmüș parseller deneme desenine göre 3 tekerrürlü olarak kurulmuștur. Araștırmada ana parsellere 3 arıtu çeșidi (Sağlamtimur, Stala, Enton), alt parsellere 5 farklı azotlu gübre dozu (0 kg/da, $2.5 \mathrm{~kg} / \mathrm{da}, 5 \mathrm{~kg} /$ da, $7.5 \mathrm{~kg} / \mathrm{da}, 10 \mathrm{~kg} / \mathrm{da}$ ) olacak șekilde uygulamalar yapıımıștır. Bitki boyu, yeșil ot verimi, kuru ot verimi, kuru madde verimi ve ham protein verimi araștırmada incelenen parametrelerdir. Alınan sonuçlara göre; 2013 ve 2014 yıllarında Stala çeșidi bitki boyu $(72.65 \mathrm{~cm}, 84.76 \mathrm{~cm})$, yeșil ot verimi $(2138.00 \mathrm{~kg} / \mathrm{da}, 2385.60$ $\mathrm{kg} / \mathrm{da})$, kuru ot verimi $(510.83 \mathrm{~kg} / \mathrm{da}, 554.60 \mathrm{~kg} / \mathrm{da})$, kuru madde verimi $(456.55 \mathrm{~kg} / \mathrm{da}, 495.99 \mathrm{~kg} / \mathrm{da}) \mathrm{ve}$ ham protein verimi $(72.92 \mathrm{~kg} / \mathrm{da}, 76.43 \mathrm{~kg} / \mathrm{da})$ bakımından diğer çeșitlere göre daha üstün olan arıotu çeșidi olmuștur. Yüksek verimli ve kaliteli üretim için tercih edilmesi gereken azot dozunun ise $10 \mathrm{~kg} / \mathrm{da}$ olduğu belirlenmiștir.

Anahtar Kelimeler: Arıotu, yeșil ot verimi, azotlu gübreleme, kalite

\section{The Effects of Different Nitrogen Fertilizer Doses on Herbage Yield and Quality of Fiddleneck (Phacelia tanacetifolia Benth.) Under Ankara Conditions}

\section{Abstract}

This research was carried out in the experimental fields of Ankara University, Faculty of Agriculture, Field Crops Department between the years of 2013 and 2014, to observe the effect of different fertilizer doses on the yield and quality parameters of fiddleneck (Phacelia tanacetifolia Benth.). The research was set up in 3 replicates compatible with split parcel experimental design tecnique in random blocks. Three different fiddleneck varieties (Sağlamtimur, Stala, Enton) were sown to main parcels and 5 different nitrogenous fertilizer doses $(0 \mathrm{~kg} / \mathrm{da}, 2.5 \mathrm{~kg} / \mathrm{da}, 7.5 \mathrm{~kg} / \mathrm{da}, 10 \mathrm{~kg} / \mathrm{da})$ were applied to sub-plots. Plant height, fresh herbage yield, hay yield, dry matter yield and crude protein yield are recorede in the experimental. CV Stala were found superior regarding it's plant height $(72.65 \mathrm{~cm}, 84.76 \mathrm{~cm})$, fresh herb yield $(2138.00 \mathrm{~kg} / \mathrm{da}$, $2385.60 \mathrm{~kg} / \mathrm{da})$, hay yield $(510.83 \mathrm{~kg} / \mathrm{da}, 554.60 \mathrm{~kg} / \mathrm{da})$, dry matter yield $(456.55 \mathrm{~kg} / \mathrm{da}, 495.99 \mathrm{~kg} / \mathrm{da})$ and crude protein yield $(72.92 \mathrm{~kg} / \mathrm{da}, 76.43 \mathrm{~kg} / \mathrm{da})$ in 2013 and 2014 . The nitrogen dose for a high-yield and high-quality production was determined as $10 \mathrm{~kg} / \mathrm{da}$.

Keywords: Fiddleneck, fresh herb yield, nitrogen fertilizing, quality

\section{Giriș}

Arıtu (Phacelia tanacetifolia BENTH.) Kuzey Amerika orjinli, Hydrophillaceae familyasına ait, $2 \mathrm{n}=22$ kromozoma sahip tek yıllık bir yem bitkisidir (Özkan ve Benlioğlu, 2015). Dik bir gövde gelișimi gösteren arıotu, 60-100 cm kadar boylanabilmektedir. Kıșı sert olan iklimlerde erken ilkbaharda yazlık olarak ve ılıman iklimlerde kıșlık ara ürün olarak ekilmektedir (Kızılșimșek ve Ateș, 2004). Ülkemiz arıcıığının en önemli sorununun koloni bașına verim (15 kg/da) düșüklüğü olduğu belirtilmektedir (Bilgen, 1999). Bu 
verimin artırıması arıların temel besin kaynağı olan nektar ve polen kaynaklarının ve florada ki yoğunluklarının artırımasına bağlıdır. Bal arıları (Apis ssp.) ve yaban arıları (Bombus ssp.) için yüksek kalitede nektar ve polen içeren arıotu, bu kaynaklar bakımından en üstün 20 bal bitkisinden biri olarak bilinmektedir (Kumova ve Korkmaz, 2002; Gillbert, 2003). Ayrıca çiçeklenme periyodu uzun, birim alandaki çiçek yoğunluğu fazladır. Pek çok tarla bitkisi içerisinde bu seviyede bir çiçeklenme periyodu görülmemektedir (Karadağ ve Büyükburç, 1999). Çiçeklenme periyodu içerisinde arı merası olarak, çiçeklenme periyodu sonunda biçilerek kaba yem, yeșil ot ve silaj olarak değerlendirilebilmektedir (Sağlamtimur ve Baytekin, 1993).

Gübreleme, verim ve kaliteyi artıran en önemli yetiștirme ișlemlerinden biri olarak bilinmektedir. Azotlu gübrelemenin arıotu'nda ot verimini ve kaliteyi artırdığı, çiçeklenme süresini uzattığı bildirilmektedir (Yılmaz, 2014). Ancak, așırı gübrelemede yapılan bazı yanlıșılılar bitkide negatif etki gösterebilmektedir. Uygulanan $12 \mathrm{~kg} / \mathrm{da}$ azot dozunun, $9 \mathrm{~kg} / \mathrm{da}$ azot dozuna göre arıotu'nda \%12'lik yeșil ot verimi kaybına sebebiyet verdiği belirlenmiștir (Yılmaz ve Albayrak, 2017). Djordjevic ve ark.'nın (2005) çalışmalarında ise $4.5 \mathrm{~kg} / \mathrm{da}$ azotlu gübrelemenin arıotu'nun kalitesine etki etmediği tespit edilmiștir. Wilczewski ve ark.'nın (2006) belirttiği üzere arıotu'na uygulanan $9 \mathrm{~kg} / \mathrm{da}$ azotlu gübrelemenin kontrol parsellerine oranla yeșil ot verimini \%82.5 artırdığı bildirilmiștir.

$\mathrm{Bu}$ araștırma, ülkemizde yetiștirilen klasik yem bitkilerinin yerine alternatif olabilecek yem bitkilerinin belirlenmesi amacıyla yapılmıștır. Aynı zamanda arıotu bitkisinin yem kalitesi ve yem verimi göz önüne alınarak ülkemizin kaba yem intiyacını kısmen de olsa karșilayabilecek yapıda olup olmayacağını belirleyebilmek araștırmamızın diğer bir amacıdır.

\section{Materyal ve Yöntem}

Araștırma 2013-2014 yıllarında Ankara Üniversitesi Ziraat Fakültesi Tarla Bitkileri Bölümü Deneme tarlalarında, 3 tekerrürlü olarak tesadüf bloklarında bölünmüș parseller deneme desenine göre kurulmuștur. Araștırma yerinin denizden yüksekliği 860 m olup, $39^{\circ} 57^{\prime}$ Kuzey enlem ve $32^{\circ} 52^{\prime}$ Doğu boylamı dereceleri arasında yer almaktadır. Araștırma yerinin toprağı killi-tınlı yapıya sahip olup, hafif alkali, kireçli, toplam tuz düzeyi zararsı, fosforca orta, potasyumca zengin ve organik maddece yetersizdir. Araștırmanın yürütüldüğü NisanTemmuz ayları arasında 2013 ve 2014 yıllarında; toplam yağıș miktarı $95.3 \mathrm{~mm}$ ve $197.2 \mathrm{~mm}$, sıcaklık ortalaması $19.42^{\circ} \mathrm{C}$ ve $18.65^{\circ} \mathrm{C}$, nispi nem oranı ise $\% 47.2$ ve $\% 53.05$ olmuștur.

Araștırmada ana parsellere arıotu çeșitleri, alt parsellere gübre dozları yerleșecek șekilde uygulamalar yapılmıștır. Parsellerin alanı $2 \mathrm{~m} \times 2 \mathrm{~m}=4 \mathrm{~m}^{2}$, sıra aralığı $40 \mathrm{~cm}$ ve 5 sıra olacak șekilde ekimi yapılmıștır. Gübre dozlarının parselleri etkilememesi için her parselin arasında $30 \mathrm{~cm}$ aralık bırakılmıș, bloklar arası boșluk $1 \mathrm{~m}$ olarak ayarlanmıștır. Dekara $1.5 \mathrm{~kg}$ tohum atılmıș olup, tohumlar $1-1.5 \mathrm{~cm}$ derinliğine 12 Nisan 2013 ve12 Nisan 2014 tarihinde ekilmișlerdir. 3 farklı arıtu çeșidi kullanımıș olup, bunlar özel sektörden elde edilmiș olan Sağlamtimur, Stala ve Enton çeșitleridir. Alt parsellerdeki gübre dozları, ekimle birlikte uygulanmıș olup $0 \mathrm{~kg} / \mathrm{da}\left(\mathrm{N}_{0}\right)$ (kontrol parseli), $2.5 \mathrm{~kg} / \mathrm{da}\left(\mathrm{N}_{1}\right), 5 \mathrm{~kg} / \mathrm{da}\left(\mathrm{N}_{2}\right), 7.5 \mathrm{~kg} / \mathrm{da}\left(\mathrm{N}_{3}\right)$ ve $10 \mathrm{~kg} / \mathrm{da}\left(\mathrm{N}_{4}\right) \mathrm{kg} / \mathrm{da}$ saf azot olacak șekilde $\% 21^{\prime}$ lik amonyum sülfat gübresi verilmiștir. Bunun yanında $2.5 \mathrm{~kg} / \mathrm{da} \mathrm{P}_{2} \mathrm{O}_{5}$ ve $2.5 \mathrm{~kg} /$ da $\mathrm{K}_{2} \mathrm{O}$ gübresi ekimle birlikte tüm parsellere verilmiștir. Gerekli görülen durumlarda yetișme periyodu süresince $2 \mathrm{kez}$ sulama ve yabancı ot mücadelesi yapılmıștır. Araștırmamızda bitki boyu, yeșil ot verimi, kuru ot verimi, kuru madde verimi ve ham protein verimi parametreleri incelenmiștir. Kuru ot verimi için; her parselden biçilmiş yeşil ottan rastgele 500 gramlık örnekler alınarak $70{ }^{\circ} \mathrm{C}$ 'de 48 saat kurutulup, daha sonra 24 saat oda koșullarında bekletildikten sonra tartılarak kuru ot ağırlığı bulunmuștur. Her parsel için elde edilen oran kullanarak dekara kuru ot verimi hesaplanmıștır (Avcl, 2000). Kuru ot verimini bulmak amaciyla kurutulmuș 500 gramlık örnekler, değirmende öğütülüp, her parsel için 3 gramlık örnekler $105^{\circ} \mathrm{C}$ 'ye ayarlı etüvde 3 saat tutularak ve sonra 0.001 gram duyarlı terazide tartılarak \% olarak kuru madde oranı ve bu oranlar üzerinden dekara kuru madde verimi hesaplanmıștır (Akyıldız, 1968). Altın (1982)'ın çalıșmaları dikkate alı- 
narak ta dekara ham protein verimleri hesaplanmıștır. Araștırmadan elde edilen veriler, tesadüf bloklarında bölünmüș parseller deneme desenine göre varyans analizine tabi tutulmuștur. Araștırmaya ait veriler Mstat-C bilgisayar programından yararlanılarak değerlendirilmiștir. İstatistiki analiz sonucunda önemli farklılık ortaya çıktığında, ortalamaların karșılaștıııması için \% 5 önemlilik düzeyinde DUNCAN testi uygulanmıștır.

\section{Bulgular ve Tartıșma}

\section{Bitki boyu}

Bitki boyu ortalamalarına göre yapılan varyans analizinde sadece 2014 yilında gübre dozu \%1 olasllık düzeyinde önemli bulunmuștur. Bununla birlikte, iki yıllık varyans analizinde yıl, gübre dozu ve yıl $x$ çeșit $x$ gübre dozunun \%1 olasılık düzeyinde önemli olduğu belirlenmiștir (Çizelge 1). Çizelge 2.'de 2013, 2014 ve iki yilın ortalamasına ait bitki boyu değerleri ayrı ayrı verilmiștir.

Farklı arıotu çeșitlerine göre bitki boyu değerleri 2013 yılında 71.25-75.20 cm, 2014 yilında $78.44-84.67 \mathrm{~cm}$, iki yılın ortalamasına göre ise 74.84-78.71 cm arasında değișim göstermiștir (Çizelge 2). Enton çeșidinde 2013, 2014 ve iki yıllık ortalamalara göre sırasıyla $75.20 \mathrm{~cm}, 78.66 \mathrm{~cm}$ ve $74.71 \mathrm{~cm}$ bitki boyu ölçülmüștür. Sağlamtimur çeșidinden ise sırasıyla $71.25 \mathrm{~cm}, 78.44 \mathrm{~cm}, 74.84 \mathrm{~cm}$ ile en düșük bitki boyu değerleri elde edilmiștir. En yüksek bitki boyu ise 2014 yılında 84.76 $\mathrm{cm}$ ile Stala çeșidinde gözlemlenmiștir. Ateș ve ark.'nın (2010) tespit ettiği şekilde tomurcuklanma dönemi ile tam çiçeklenme

Çizelge 1. Farklı arıotu çeșitleri ve azotlu gübre dozlarına ait varyans analizi (kareler ortalaması)

Table 1. Varience analysis of different varieties and nitrogen fertilizer doses of fiddleneck (mean square)

\begin{tabular}{|c|c|c|c|c|c|}
\hline Varyasyon kaynakları & $\begin{array}{l}\text { Bitki Boyu } \\
\text { (cm) }\end{array}$ & $\begin{array}{c}\text { Yeșil ot verimi } \\
\text { (kg/da) }\end{array}$ & $\begin{array}{l}\text { Kuru ot verimi } \\
\text { (kg/da) }\end{array}$ & $\begin{array}{c}\text { Kuru madde } \\
\text { verimi } \\
\text { (kg/da) }\end{array}$ & $\begin{array}{c}\text { Ham Protein } \\
\text { Verimi } \\
\text { (kg/da) }\end{array}$ \\
\hline \multicolumn{6}{|c|}{2013} \\
\hline Çeșit & 60.27 & $683565.27^{* *}$ & $41410.70^{* *}$ & $33029.54^{\star \star}$ & $534.89^{*}$ \\
\hline Hata & 72.16 & 18007.77 & 1272.03 & 1055.67 & 38.64 \\
\hline Gübre dozu & 28.34 & $331578.61^{* *}$ & $43717.68^{* *}$ & $34224.03^{\star \star}$ & $1702.13^{* *}$ \\
\hline Çeșit x Gübre dozu & 30.06 & $20153.04^{* *}$ & $1683.37^{\star *}$ & $1323.01^{\star \star}$ & 39.69 \\
\hline Hata & 12.97 & 2967.40 & 445.12 & 336.69 & 128.26 \\
\hline \multicolumn{6}{|c|}{2014} \\
\hline Çeșit & 193.74 & $1587170.60^{* *}$ & $78000.30^{* *}$ & $63017.97^{\star *}$ & $1419.25^{\star *}$ \\
\hline Hata & 119.82 & 49805.63 & 3043.48 & 2503.13 & 71.00 \\
\hline Gübre dozu & $26.18^{* *}$ & $398643.52^{* *}$ & $48271.81^{* *}$ & $37655.64^{* *}$ & $2710.26^{\star *}$ \\
\hline Çeșit x Gübre dozu & 3.45 & $42298.82^{* *}$ & $2858.04^{* *}$ & $2322.59^{* *}$ & $109.03^{* *}$ \\
\hline Hata & 5.18 & 3219.82 & 214.09 & 178.32 & 7.43 \\
\hline \multicolumn{6}{|c|}{ İki yıllık } \\
\hline YIl & $1298.38^{\star \star}$ & $449612.44^{* *}$ & $16461.41^{* *}$ & $1308.47^{*}$ & 48.93 \\
\hline Blok & 77.02 & 32056.05 & 1698.49 & 1156.13 & 14.62 \\
\hline Çeșit & 112.39 & $2163865.36^{\star *}$ & $116097.90^{\star *}$ & $93298.87^{\star *}$ & $1813.59^{* *}$ \\
\hline YIl x Çeșit & 141.61 & 106870.51 & 3313.09 & 2748.64 & 140.55 \\
\hline Hata & 95.99 & 33906.70 & 2157.75 & 1779.40 & 54.82 \\
\hline Gübre dozu & $35.47^{\star *}$ & $724070.02^{* *}$ & $91383.55^{* *}$ & $71417.19^{* *}$ & $4245.26^{* *}$ \\
\hline Yıl x Gübre dozu & 19.06 & 6152.11 & 605.94 & 462.48 & 167.14 \\
\hline Çeșit x Gübre dozu & 13.77 & $57508.40^{* *}$ & $4276.24^{* *}$ & $3423.02^{* \star}$ & 118.44 \\
\hline Yıl x Çeșit x Gübre Dozu & $19.74^{*}$ & 4943.46 & 265.18 & 222.58 & 30.28 \\
\hline Hata & 9.08 & 3093.61 & 329.61 & 257.51 & 67.75 \\
\hline
\end{tabular}

$0.05 ;{ }^{* \star} 0.01$ önem düzeyinde farklılı̆̆ göstermektedir.

${ }^{*} 0.05,{ }^{* \star} 0.01$ shows significant probability level. 
Çizelge 2. Farklı çeșit ve gübre dozlarının bitki boyu ortalamaları (cm)

Table 2. Different cultivar and nitrogen doses of plant height means (cm)

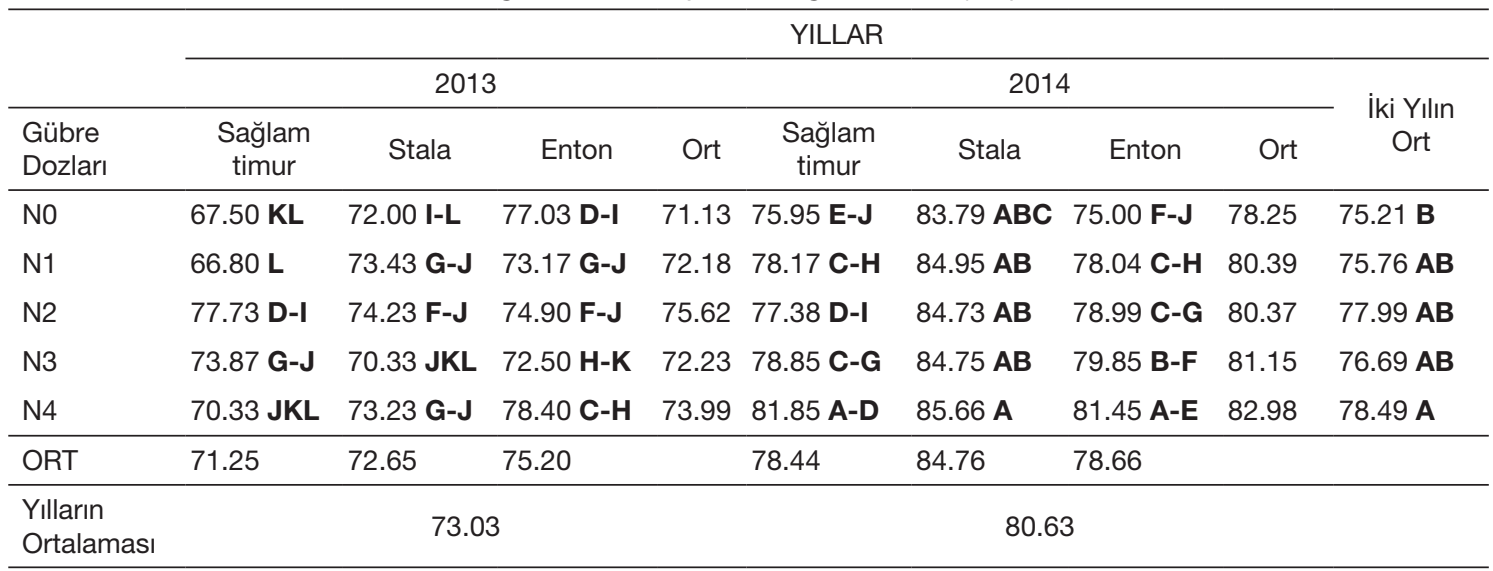

döneminde arıotunun bitki boyunun 103.66$106.33 \mathrm{~cm}$ arasında olduğu bildirilmiștir.

Farklı gübre dozlarına ait bitki boyu değerleri 2013 yllında $71.13-75.62 \mathrm{~cm}, 2014$ yllında 78.25-82.98 cm, iki yllın ortalamasına göre 75.21-78.49 cm arasında değișim göstermiştir (Çizelge 2). $10 \mathrm{~kg} / \mathrm{da}$ azot uygulaması en yüksek bitki boyu değerlerini verirken, gübre uygulaması yapılmayan kontrol parsellerinde en düșük bitki boyu değerleri alınmıștır. $10 \mathrm{~kg} /$ da azot uygulamasında 2013, 2014 ve iki yllın ortalamasına göre sırasıyla $73.99 \mathrm{~cm}, 82.98$ $\mathrm{cm}, 78.49 \mathrm{~cm}$ bitki boyu ölçülmüștür. Gübre uygulaması yapılmayan kontrol parsellerinde ise sırasıyla $71.13 \mathrm{~cm}, 78.25 \mathrm{~cm}, 75.21 \mathrm{~cm}$ bitki boyu elde edilmiștir. Tuncer'in (2014) 5 kg/da' dan 10 kg/da'a kadar uyguladığı azot dozlarında arıotunda bitki boyunun arttığı belirlenmiș ve en yüksek bitki boyu $64.55 \mathrm{~cm}$ olarak ölçmüștür.

Yıl $x$ çeșit $x$ gübre dozu interaksiyonuna göre en yüksek bitki boyu 2014 yllında Stala çeșidinde $84.95 \mathrm{~cm}$ olara ölçülürken, en düșük bitki boyu ise 2013 yılında Sağlamtimur çeșidinden $66.80 \mathrm{~cm}$ olarak ölçülmüștür. Bununla birlikte; bitki boyları 2014 yılında 2013 yılına göre \%10.40'lık bir artıș göstermiștir.

\section{Yeșil ot verimi}

Yeșil ot verimine ait ortalamalara göre yapılan varyans analizinde 2013, 2014 yıllarında çeșit, gübre dozu, çeșit x gübre dozu \%1 olasılık düzeyinde önemli bulunmuștur. Bunula birlikte, iki yıllık varyans analizinde yıl, çeșit, gübre dozu, çeșit x gübre dozunun $\% 1$ olasılık düzeyinde önemli olduğu belirlenmiștir (Çizelge 1). Çizelge 3.'te 2013, 2014 yılları ile iki yılın ortalamasına ait yeșil ot verimi değerleri ayrı ayrı verilmiștir.

Farklı arıtu çeșitlerine göre yeșil ot verimi ortalamaları 2013 yılında 1727.33-2138.47 $\mathrm{kg} / \mathrm{da}, 2014$ yilında $1739.27-2385.60 \mathrm{~kg} / \mathrm{da}$, iki yılın ortalamasına göre 1714.29-2199.50 kg/da arasında değișmiștir (Çizelge 3). Stala çeșidinden sırasıyla, 2013 yılında $2138.47 \mathrm{~kg} /$ da, 2014 yılında 2385.60, iki yılın ortalamasına göre $2262.03 \mathrm{~kg} / \mathrm{da}$ ile en yüksek yeșil ot verimi alınmıștır. En düșük yeșil ot verimi Enton çeșidinden 2013 yllında 1727.33 kg/da, 2014 yılında $1739.27 \mathrm{~kg} / \mathrm{da}$, iki yılın ortalamasına göre 1733.30 kg/da olarak elde edilmiștir.

Çeşit x gübre dozu interaksiyonu 2013 yılında $1506.00-2375.00 \mathrm{~kg} / \mathrm{da}$ arasında, 2014 yılında $1547.41-2540.67 \mathrm{~kg} / \mathrm{da}$ arasında değișim göstermiștir (Çizelge 3). Her iki yılda da, Stala çeșidi $10 \mathrm{~kg} / \mathrm{da}$ gübre dozunda en yüksek yeșil ot verimini verirken, Sağlamtimur çeșidi gübre uygulaması yapılmayan kontrol parsellerinde en düșük verimi vermiștir. Yılmaz ve Albayrak'ın (2017) Eskișehir koșullarında yaptıkları çalıșmalarında $9 \mathrm{~kg} / \mathrm{da}$ azot uygulaması ile Stala çeșidinden $2103 \mathrm{~kg} /$ da yeșil ot veriminin elde edildiğini bildirmișlerdir. $7.5 \mathrm{~kg} / \mathrm{da}$ ve 10 $\mathrm{kg} / \mathrm{da}$ azot uygulanan parsellerde Stala çeșidi diğer arıotu çeșitlerinden belirgin olarak daha yüksek yeșil ot vermiștir.

Farklı gübre dozlarının yeșil ot verimine ait ortalamaları 2013 yılında 1669.44-2132.79 kg/da, 2014 yllında 1759.14-2266.22 kg/da, 
Çizelge 3. Farklı çeșit ve gübre dozlarının yeșil ot verimi ortalamaları (kg/da)

Table 3. Different cultivar and nitrogen doses of fresh herbage yield means (kg/da)

\begin{tabular}{|c|c|c|c|c|c|c|c|c|c|}
\hline \multirow[b]{3}{*}{$\begin{array}{l}\text { Gübre } \\
\text { Dozları }\end{array}$} & \multicolumn{9}{|c|}{ YILLAR } \\
\hline & \multicolumn{4}{|c|}{2013} & \multicolumn{4}{|c|}{2014} & \multirow{2}{*}{$\begin{array}{l}\text { İki Yılın } \\
\text { Ort }\end{array}$} \\
\hline & $\begin{array}{l}\text { Sağlam } \\
\text { timur }\end{array}$ & Stala & Enton & Ort & $\begin{array}{c}\text { Sağlam } \\
\text { timur }\end{array}$ & Stala & Enton & Ort & \\
\hline No & $1506.00 \mathrm{~J}$ & $1902.33 \mathbf{E}$ & 1600.00 I & 1669.44 & 1547.41 I & 2152.33 D & 1577.67 I & 1759.14 & 1714.29 \\
\hline N1 & $1630.00 \mathrm{HI}$ & 2010.00 D & $1650.00 \mathrm{HI}$ & 1763.33 & $1790.00 \mathrm{FG}$ & 2233.33 CD & $1676.33 \mathbf{H}$ & 1899.89 & 1831.61 \\
\hline N2 & 1833.33 EF & 2111.67 BC & $1716.67 \mathrm{GH}$ & 1887.22 & $2019.00 \mathrm{E}$ & $2468.00 \mathrm{AB}$ & $1749.00 \mathrm{GH}$ & 2078.67 & 1982.94 \\
\hline N3 & 2043.33 CD & 2293.33 A & $1800.00 \mathrm{FG}$ & 2045.56 & $2253.00 \mathrm{C}$ & $2533.37 \mathbf{A}$ & 1817.00 FG & 2201.22 & 2123.39 \\
\hline N4 & 2153.33 B & $2375.00 \mathrm{~A}$ & $1870.00 \mathrm{EF}$ & 2132.79 & 2381.67 B & $2540.67 \mathrm{~A}$ & $1876.33 \mathbf{F}$ & 2266.22 & 2199.50 \\
\hline ORT & 1833.20 & 2138.47 & 1727.33 & & 1998.21 & 2385.60 & 1739.27 & & \\
\hline $\begin{array}{l}\text { Yılların } \\
\text { Ortalaması }\end{array}$ & & 1899. & & & & 2041. & .03 & & \\
\hline
\end{tabular}

iki yılın ortalamasına göre 1714.29-2199.50 $\mathrm{kg} / \mathrm{da}$ arasında değișim göstermiștir (Çizelge 3). Uygulanan azot dozlarının artıșına bağı olarak yeșil ot verimlerinde artıșlar meydana gelmiștir. Çizelge 3.'de görüldüğü üzere gübre uygulaması yapılmayan kontrol parsellerinde en düșük yeșil ot verimi alınırken, $10 \mathrm{~kg} / \mathrm{da}$ azot uygulanan parsellerde en yüksek yeșil ot verimleri elde edilmiștir. $10 \mathrm{~kg} / \mathrm{da}$ azot uygulanan parsellerde 2013 yllında 2132.78 $\mathrm{kg} / \mathrm{da}, 2014$ yllında $2266.22 \mathrm{~kg} / \mathrm{da}$, iki yllın ortalamasına göre $2199.50 \mathrm{~kg} / \mathrm{da}$ ile yeșil ot verimi bakımından en yüksek değerlere ulașılmıștır. Gübre uygulaması yapılmayan kontrol grubu parsellerinde 2013 yilında 1669.44 kg/da, 2014 yılında 1759.14 kg/da, iki ylın ortalamasınagöre ise $1714.29 \mathrm{~kg} /$ dayeșil ot verimi alınmıștır. Arıotun'da dekara uygulanan $10 \mathrm{~kg}$ azotlu gübrelemenin kontrol parsellerine göre yeșil ot verimini 2013 yilında \%27.80, 2014 yllında \%28.82, iki yılın ortalamasına göre \%28.30 artırdığı belirlenmiștir. Wilczewski ve ark.'nın (2008) Polonya koșullarında, Ateș ve ark.'nın (2014) Tekirdağ koșullarında azotlu gübrelemenin arıotu'nun verim ve kalitesine olan etkileri incelenmiș olup, en yüksek verim ve kalitede arıotu için $9 \mathrm{~kg} / \mathrm{da}$ azotlu gübre uygulamasının uygun olacağı belirlenmiștir. Yılmaz ve Albayrak'ın (2017) araștırmasında $9 \mathrm{~kg} / \mathrm{da}$ azotlu gübre uygulamasının ortalama $2496 \mathrm{~kg} / \mathrm{da}$ yeșil ot verimi verdiği belirlenmiș ve bu sonuç araștırmamızdan daha yüksek bulunmuștur.

\section{Kuru ot verimi}

Kuru ot verimine ait ortalamalara göre yapılan varyans analizinde 2013, 2014 yıllarında çeșit, gübre dozu, çeșit x gübre dozu \%1 olasılık düzeyinde önemli bulunmuștur. Bunula birlikte, iki yıllık varyans analizinde yıl, çeșit, gübre dozu, çeșit $x$ gübre dozu interaksiyonunun \%1 düzeyinde önemli olduğu belirlenmiştir. Çizelge 4.'te 2013, 2014 ve iki yılın ortalamasına ait kuru ot verimi değerleri ayrı ayrı verilmiștir.

Farklı arıotu çeșitlerine göre kuru ot verimi ortalamaları 2013 yılında $406.97-510.83 \mathrm{~kg} /$ da, 2014 yilında 410.44-554.60 kg/da, iki yılın ortalamasına göre 408.71-532.72 kg/ da arasında değișmektedir. Stala çeșidi 2013 yllında 510.83 kg/da, 2014 yllında 554.60 kg/ da, iki yılın ortalamasına göre $532.72 \mathrm{~kg} / \mathrm{da}$ ile en yüksek kuru ot verimini vermiștir. Enton çeşidinden ise 2013 yllında $406.97 \mathrm{~kg} / \mathrm{da}$, 2014 yılında 410.60, iki yılın ortalamasına göre $408.71 \mathrm{~kg} / \mathrm{da}$ ile en düșük kuru ot verimi elde edilmiștir. Yılmaz ve Albayrak'ın çalıșmalarında (2017) 9 kg/da azotlu gübre uygulaması ile Enton çeșidinden $722 \mathrm{~kg} / \mathrm{da}$, Stala çeșidinden ise $537 \mathrm{~kg} / \mathrm{da}$, Tuncer'in (2014) araștırmasında $7.5 \mathrm{~kg} / \mathrm{da}$ azotlu gübre uygulamasından 569.13 $\mathrm{kg} / \mathrm{da} \mathrm{kuru}$ ot veriminin alındığı sonuçları araștırmamızdan daha yüksek bulunmuștur.

Çeşit x gübre dozu interaksiyonu 2013 yilında $339.67-601.69 \mathrm{~kg} / \mathrm{da}$ arasında, 2014 yılında 344.98-627.57 kg/da arasında değișim göstermiștir (Çizelge 4). Her iki yılda da, Stala çeșidi $10 \mathrm{~kg} / \mathrm{da}$ gübre dozunda en yüksek kuru ot verimini verirken, Sağlamtimur çeșidi gübre uygulaması yapılmayan kontrol parsellerinde en düșük kuru ot verimini vermiștir. 
Çizelge 4. Farklı çeșit ve gübre dozlarının kuru ot verimi ortalamaları $(\mathrm{kg} / \mathrm{da})$

Table 4. Different cultivar and nitrogen doses of hay yield means ( $\mathrm{kg} / \mathrm{da})$

\begin{tabular}{|c|c|c|c|c|c|c|c|c|c|}
\hline \multirow[b]{3}{*}{$\begin{array}{l}\text { Gübre } \\
\text { Dozları }\end{array}$} & \multicolumn{9}{|c|}{ YILLAR } \\
\hline & \multicolumn{4}{|c|}{2013} & \multicolumn{4}{|c|}{2014} & \multirow{2}{*}{$\begin{array}{c}\text { - İki Yilın } \\
\text { Ort }\end{array}$} \\
\hline & $\begin{array}{l}\text { Sağlam } \\
\text { timur }\end{array}$ & Stala & Enton & Ort & $\begin{array}{l}\text { Sağlam } \\
\text { timur }\end{array}$ & Stala & Enton & Ort & \\
\hline No & $339.67 \mathbf{H}$ & $424.11 \mathrm{E}$ & 350.84 GH & 371.54 & 344.98 G & 469.27 DE & $345.55 \mathbf{G}$ & 386.60 & 379.07 \\
\hline N1 & $382.60 \mathrm{FG}$ & $465.00 \mathrm{CD}$ & 378.82 FG & 408.81 & $411.67 \mathrm{~F}$ & $497.20 \mathrm{C}$ & $388.90 \mathrm{~F}$ & 432.59 & 420.70 \\
\hline N2 & 435.73 DE & $499.19 \mathrm{C}$ & $402.84 \mathrm{EF}$ & 445.92 & 476.45 CD & 567.68 B & $410.98 \mathrm{~F}$ & 485.03 & 465.48 \\
\hline N3 & 495.22 C & 564.17 B & 436.78 DE & 498.72 & 558.06 B & $611.29 \mathrm{~A}$ & $445.17 \mathrm{E}$ & 538.17 & 518.45 \\
\hline N4 & $571.64 \mathrm{AB}$ & $601.69 \mathrm{~A}$ & $465.64 \mathrm{CD}$ & 546.32 & $603.29 \mathrm{~A}$ & $627.57 \mathrm{~A}$ & 461.61 DE & 564.16 & 555.24 \\
\hline ORT & 444.97 & 510.83 & 406.97 & & 478.89 & 554.60 & 410.44 & & \\
\hline $\begin{array}{l}\text { Yılların } \\
\text { Ortalaması }\end{array}$ & 454.26 & & & & 481.31 & & & & \\
\hline
\end{tabular}

Farklı gübre dozlarına göre kuru ot verimi ortalamaları 2013 yilında $371.54-546.32 \mathrm{~kg} /$ da, 2014 yilında $386.60-564.16 \mathrm{~kg} / \mathrm{da}$, iki ylın ortalamasına göre $379.07-555.24 \mathrm{~kg} /$ da arasında değișmiștir (Çizelge 4). $10 \mathrm{~kg} /$ da azot uygulanan parsellerde en yüksek kuru ot verimleri elde edilmiștir. 2013 yılında $546.32 \mathrm{~kg} / \mathrm{da}, 2014$ yılında $564.16 \mathrm{~kg} / \mathrm{da}$, iki yilın ortalamasına göre $555.24 \mathrm{~kg} / \mathrm{da}$ kuru ot verimi alınmıștır. En düșük kuru ot verimleri gübre uygulaması yapılmayan kontrol grubu parsellerinde görülmüștür. Arıotun'da uygulanan $10 \mathrm{~kg} / \mathrm{da}$ azotlu gübrelemenin kontrol parsellerine göre kuru ot verimini 2013 yilında \%47.04, 2014 yilında \%45.92, iki yılın ortalamasına göre \%46.47 artırdığı belirlenmiștir. Kuru ot veriminin arıotun'da azotlu gübrelemeye bağı olarak artıș gösterdiği birçok araștııcı tarafından da saptanmıștır (Wilczewski ve ark., 2008; Wilczewski ve ark., 2009; Dağ, 2013; Ateș ve ark., 2014).

\section{Kuru madde verimi}

Kuru madde verimine ait ortalamalara göre yapılan varyans analizinde 2013, 2014 yıllarında çeșit, gübre dozu, çeșit $x$ gübre dozu interaksiyonu \%1 düzeyinde önemli bulunmuștur. Bununla birlikte, iki yıllık varyans analizinde yıl, çeșit, gübre dozu, çeșit $x$ gübre dozu interaksiyonunun \%1 düzeyinde önemli olduğu belirlenmiștir (Çizelge 1). Çizelge 5.'de 2013, 2014 ve iki yılın ortalamasına ait kuru madde verimi değerleri ayrı ayrı verilmiștir.

Farklı arıotu çeșitlerine göre kuru madde verimine ait ortalamalar 2013 yilında 363.74$456.55 \mathrm{~kg} / \mathrm{da}, 2014$ yllında $366.39-495.99 \mathrm{~kg} /$ da, iki yılın ortalamasına göre 365.06-476.27 $\mathrm{kg} / \mathrm{da}$ arasında değișmiștir (Çizelge 5). Stala çeșidi her iki yılda ve iki yılın ortalamasında göre en yüksek kuru madde verimini vermiștir. Enton çeșidinden ise en düșük kuru madde verimi elde edilmiștir. Richards ve ark.'। (1996)

Çizelge 5. Farklı çeșit ve gübre dozlarının kuru madde verimi ortalamaları (kg/da)

Table 5. Different cultivar and nitrogen doses of dry matter yield means (kg/da)

\begin{tabular}{|c|c|c|c|c|c|c|c|c|c|}
\hline \multirow[b]{3}{*}{$\begin{array}{l}\text { Gübre } \\
\text { Dozları }\end{array}$} & \multicolumn{9}{|c|}{ YILLAR } \\
\hline & \multicolumn{4}{|c|}{2013} & \multicolumn{4}{|c|}{2014} & \multirow{2}{*}{$\begin{array}{c}\text { İki Yılın } \\
\text { Ort }\end{array}$} \\
\hline & $\begin{array}{l}\text { Sağlam } \\
\text { timur }\end{array}$ & Stala & Enton & Ort & $\begin{array}{l}\text { Sağlam } \\
\text { timur }\end{array}$ & Stala & Enton & Ort & \\
\hline No & $304.66 \mathbf{H}$ & $379.91 \mathrm{E}$ & 313.68 GH & 332.75 & $308.70 \mathrm{G}$ & 420.86 D & $309.01 \mathbf{G}$ & 346.19 & 339.47 \\
\hline N1 & $342.60 \mathrm{FG}$ & 415.86 CD & 339.34 FG & 365.93 & $368.63 \mathrm{~F}$ & $445.83 \mathrm{C}$ & $348.63 \mathrm{~F}$ & 387.70 & 376.82 \\
\hline N2 & $390.50 \mathrm{DE}$ & $446.06 \mathrm{C}$ & $360.11 \mathrm{EF}$ & 398.89 & $426.98 \mathrm{CD}$ & 507.07 B & $366.95 \mathrm{~F}$ & 433.67 & 416.28 \\
\hline N3 & $443.17 \mathrm{C}$ & 504.14 B & 390.23 DE & 445.85 & 499.47 B & $546.20 \mathrm{~A}$ & $395.85 \mathrm{E}$ & 480.51 & 463.18 \\
\hline N4 & 509.63 АВ & $536.79 \mathbf{A}$ & 415.32 CD & 487.25 & $538.11 \mathrm{~A}$ & $559.96 \mathbf{A}$ & 411.52 DE & 503.20 & 495.22 \\
\hline ORT & 398.11 & 456.55 & 363.74 & & 428.38 & 495.99 & 366.39 & & \\
\hline $\begin{array}{l}\text { Yılların } \\
\text { Ortalaması }\end{array}$ & & \multicolumn{3}{|c|}{406.13} & \multicolumn{4}{|c|}{430.25} & \\
\hline
\end{tabular}


İngiltere koșullarında $128 \mathrm{~kg} / \mathrm{da}$, Amerika Birleșik Devletlerinde Stivers-Young'ın (1996) ve Wyland ve ark.'nın (1996) sırasıyla 300 $\mathrm{kg} / \mathrm{da}$ ve $364 \mathrm{~kg} / \mathrm{da}$, ülkemizde Bașbağ ve ark.'nın (2001) 472-600 kg/da, Karadağ ve Büyükburç'un (2001) 334-521 kg/da, Karadağ ve Büyükburç'un (2003) $55-221$ kg/da, Bakoğlu ve Kutlu'nun (2006) $305.5 \mathrm{~kg} / \mathrm{da}$, Lermi ve Palta'nın (2014) çalışmalarında 212 kg/da kuru madde verimi elde edildiği belirtilmiștir.

Çeşit x gübre dozu interaksiyonu 2013 yilında $304.66-536.79 \mathrm{~kg} / \mathrm{da}$ arasında, 2014 yllında $308.70-559.96 \mathrm{~kg} / \mathrm{da}$ arasında değișim göstermiștir. Her iki yılda da, Stala çeșidi $10 \mathrm{~kg} / \mathrm{da}$ gübre dozunda en yüksek yeșil ot verimini verirken, Sağlamtimur çeșidi gübre uygulaması yapılmayan kontrol parsellerinde en düșük verimi vermiștir. İkinci yılda yağış miktarının fazlalığı nedeniyle $10 \mathrm{~kg} / \mathrm{da}$ azot verilen parsellerde kuru madde verimleri daha fazla olmuştur. Yağışın etkisi ile azot bitkilerde verim artışına neden olmuştur. Bitkiler azottan daha iyi yararlanmaya başlamıştır.

Farklı gübre dozlarının kuru madde verimine ait ortalamaları 2013 yılında 332.75$487.25 \mathrm{~kg} / \mathrm{da}, 2014$ yilında $346.19-503.20 \mathrm{~kg} /$ $\mathrm{da}$, iki yılın ortalamasına göre 339.47-495.22 $\mathrm{kg} / \mathrm{da}$ arasında değișim göstermiștir (Çizelge 5). $10 \mathrm{~kg} / \mathrm{da}$ azot uygulanan parsellerde en yüksek kuru madde verimleri elde edilirken gübre dozu uygulanmayan kontrol grubu parsellerde en düșük kuru madde verimi elde edilmiștir. Arıotun'da uygulanan $10 \mathrm{~kg} / \mathrm{da}$ azotlu gübrelemenin kontrol parsellerine göre kuru madde verimini 2013 yllında $\% 46.43$,
2014 yllında \%45.35, iki yilın ortalamasına göre \%45.88 artırdığı belirlenmiștir.

\section{Ham protein verimi}

Ham protein verimine ait ortalamalara göre yapılan varyans analizinde 2013 yılında çeșit ve gübre dozu \%1 olasılık düzeyinde, 2014 yılında çeșit, gübre dozu, çeșit $x$ gübre dozu interaksiyonu \%1 düzeyinde önemli olmuștur. İki yıllık varyans analizine göre ham protein verimine, çeșit ve gübre dozunun etkisi $\% 1$ olasılık düzeyinde önemli olarak belirlenmiștir (Çizelge 1). Çizelge 6.'da 2013, 2014 ve iki yilın ortalamasına ait ham protein verimi değerleri ayrı ayrı verilmiștir.

Farklı arıotu çeșitlerine göre ham protein verimine ait ortalamalar 2013 yilında 61.33$72.92 \mathrm{~kg} / \mathrm{da}, 2014$ yilında 56.99-76.43 kg/da, iki yılın ortalamasına göre $59.16-74.67 \mathrm{~kg} /$ da arasındadır (Çizelge 6). 2013, 2014 ve iki yılın ortalamasına göre yılında Stala çeșidi en yüksek ham protein verimine sahip olmuștur. Enton çeșidinde yeșil ot verimi, kuru ot verimi, kuru madde verimine benzer șekilde ham protein veriminde de en düșük değerler ile karșılașılmıștır. Tuncer'in (2014) araștırmasında Sağlamtimur çeșidinden 90.40 kg/da, Yılmaz ve Albayrak'ın (2017) araștırmalarında Enton çeșidinden $89.95 \mathrm{~kg} / \mathrm{da}$ ve Stala çeșidinden $59.42 \mathrm{~kg} / \mathrm{da}$ ham protein verimleri alındığı belirtilmiștir.

Çeşit x gübre dozu interaksiyonu 2013 yllında 47.16-95.16 kg/da arasında, 2014 yılında 39.56-96.13 kg/da arasında değișim göstermiștir (Çizelge 6). Her iki yılda da, Stala

Çizelge 6. Farklı çeșit ve gübre dozlarının ham protein verimi ortalamaları (kg/da)

Table 6. Different cultivar and nitrogen doses of crude protein yield means ( $\mathrm{kg} / \mathrm{da}$ )

\begin{tabular}{|c|c|c|c|c|c|c|c|c|c|}
\hline \multirow[b]{3}{*}{$\begin{array}{l}\text { Gübre } \\
\text { Dozları }\end{array}$} & \multicolumn{9}{|c|}{ YILLAR } \\
\hline & \multicolumn{4}{|c|}{2013} & \multicolumn{4}{|c|}{2014} & \multirow{2}{*}{$\begin{array}{l}\text { İki Yılın } \\
\text { Ort }\end{array}$} \\
\hline & $\begin{array}{l}\text { Sağlam } \\
\text { timur }\end{array}$ & Stala & Enton & Ort & $\begin{array}{l}\text { Sağlam } \\
\text { timur }\end{array}$ & Stala & Enton & Ort & \\
\hline NO & 50.85 & 53.66 & 47.16 & $50.58 \mathrm{C}$ & $39.56 \mathbf{H}$ & $51.79 \mathrm{G}$ & $40.61 \mathbf{H}$ & 43.99 & 47.28 \\
\hline N1 & 61.84 & 68.81 & 57.04 & $62.56 \mathrm{~B}$ & $50.28 \mathbf{G}$ & $61.80 \mathrm{EF}$ & $51.68 \mathbf{G}$ & 54.59 & 58.58 \\
\hline N2 & 68.06 & 68.85 & 61.04 & 65.98 B & 65.29 DE & $80.75 \mathrm{C}$ & $58.79 \mathrm{~F}$ & 68.28 & 67.13 \\
\hline N3 & 73.18 & 78.12 & 66.81 & 72.71 B & $81.64 \mathrm{C}$ & 91.48 B & $64.91 \mathrm{DE}$ & 79.35 & 76.03 \\
\hline N4 & 94.11 & 95.16 & 74.52 & 87.93 A & 93.32 AB & $96.31 \mathrm{~A}$ & $68.94 \mathrm{D}$ & 86.19 & 87.06 \\
\hline ORT & $69.61 \mathrm{~A}$ & $72.92 \mathbf{A}$ & 61.33 B & & 66.02 & 76.43 & 56.99 & & \\
\hline $\begin{array}{l}\text { Yılların } \\
\text { Ortalaması }\end{array}$ & & \multicolumn{3}{|c|}{67.95} & \multicolumn{4}{|c|}{66.45} & \\
\hline
\end{tabular}


çeșidi $10 \mathrm{~kg} / \mathrm{da}$ gübre dozunda en yüksek ham protein verimini verirken, en düșük verim ise 2013 yilında Enton çeșidinden, 2014 yılında Sağlamtimur çeșidinden gübre uygulaması yapılmayan parsellerden elde edilmiștir.

Farklı gübre dozlarına göre ham protein verimine ait ortalama değerler 2013 yılında $50.58-87.93 \mathrm{~kg} / \mathrm{da}, 2014$ yilında $43.99-86.19$ $\mathrm{kg} / \mathrm{da}$, iki yilın ortalamasına göre 47.28-87.06 $\mathrm{kg} / \mathrm{da}$ arasında değișim göstermiştir (Çizelge 6). $10 \mathrm{~kg} / \mathrm{da}$ azot uygulanan parsellerde en yüksek ham protein verimleri alınmıș olup, sırasıyla 2013 ylında $87.93 \mathrm{~kg} / \mathrm{da}, 2014$ yılında $86.19 \mathrm{~kg} / \mathrm{da}$, iki yılın ortalamasına göre ise $87.06 \mathrm{~kg} / \mathrm{da}$ ham protein verimi alınmıștır. Arıotun'da uygulanan $10 \mathrm{~kg} / \mathrm{da}$ azotlu gübrelemenin kontrol parsellerine göre ham protein verimini 2013 yllında \%73.84, 2014 yilında \%95.93, iki yilın ortalamasına göre $\% 84.13$ artırdığı belirlenmiștir. Azotlu gübre uygulamalarının olumlu etkisi incelenen diğer parametrelere nazaran ham protein veriminde daha fazla olmuștur. Lermi ve Palta'nın (2014) araștırmalarında Bartın șartlarında arıotun'da $25 \mathrm{~kg} / \mathrm{da}$ ham protein verimi elde etmișlerdir. Yılmaz ve Albayrak'ın (2017) tespit ettiği üzere ise $9 \mathrm{~kg} / \mathrm{da}$ azotlu gübre uygulaması ile ortalama $98.01 \mathrm{~kg} / \mathrm{da}$ ham protein verimi alındığı belirlenmiştir.

\section{Sonuç}

Farklı arıotu çeșitlerinde uygulanan farklı azot dozları ele alındığında Stala çeșidi yeșil ot, kuru ot, kuru madde ve ham protein verimi bakımından en yüksek verimi vermiștir. Bunun yanında Sağlamtimur yeșil ot, kuru ot ve ham protein verimi bakımından ise orta düzey verim vermiștir. Enton çeșidi verim öğeleri bakımından en düșük seviyede verim veren arıotu çeșidi olmuștur. Bu çeșitlere uygulanan gübre dozları göz önüne alındığında en yüksek verim, ele alınan kriterler bakımından $10 \mathrm{~kg} / \mathrm{da}$ azot dozu uygulanan parsellerden alınmıștır. Yağıșın fazla olduğu ikinci yılda bitkilerin azot dozlarına verdiği cevap oldukça yüksek düzeyde olmuștur. Seçtiğimiz azot dozlarının daha üst miktarda verilmesi durumunda verimde artıșlarda görülebilir. Orta Anadolu koșullarında Stala çeșidi hem verim bakımından, hem de kalite bakımından iyi değerler verirken, uygulanan $10 \mathrm{~kg} / \mathrm{da}$ 'lık azot dozu da en yüksek miktarda ve kalitede ürün sağlamıştır.

\section{Kaynaklar}

Akyıldız, A.R. (1968). Yemler Bilgisi Laboratuvar Kılavuzu. A.Ü. Ziraat Fakültesi Yayınları, 358. Uygulama Kilavuzu, 122-214.

Altın, M. (1982). Erzurum Șartlarında Bazı Yem bitkileri Ile Bunların Karıșımlarının Değișik Azot Dozlarındaki Kuru Ot ve Ham Protein Verimleri ile Karıșımların Botanik Kompozisyonlar. TÜBiTAK VII. Bilim Kongresi, 552/TOAG 115327-344.

Ates, E., Coskuntuna, L., \& Tekeli, A.S. (2010). Plant growth stage effects on the yield, feeding value and some morphological characters of the fiddleneck (Phacelia tanacetifolia Benth.). Cuban Journal of Agricultural Science, 44(4).

Ates, E., Tekeli, A.S., \& Boynukara, B. (2014). Performance of Fodder Pea (Pisum arvense L.)- Fiddleneck (Phacelia tanacetifolia BENTH.) Mixture Under Different Nitrogen Doses. Romanian Agricultural Research, 31, 213-218.

Avcl, M. (2000). Çukurova'da Geçici Yapay Mera Kurmak Amacıyla Yetiștirilebilecek Kıșlık Çok Yıllık Buğdaygil - Baklagil Yem Bitkileri Karıșımlarının Saptanması. Ç.Ü. Fen Bilimleri Enstitüsü, Doktora Tezi, $113 \mathrm{Sf}$, Adana.

Bakoğlu, A., \& Kutlu, M.A. (2006). Bingöl Sulu Șartlarında Yetișen Arıotu (Phacelia tanacetifolia Bentham)'na Uygulanan Değișik Sıra Aralığııın Bazı Tarımsal Özelliklere Ve Arı Merası Olarak Kullanılmasına Etkisi Üzerine Bir Araștırma, 3338.

Bașbağ, M., Saruhan, V., Gül, İ. (2001). Diyarbakır Koșullarında Farklı Tohumluk Miktarlarının Arıotu (Phacelia tanacetifolia Benth.)'nda Bazı Tarımsal Özellikler Üzerine Etkisi, GAP 2. Tarım Kongresi, 24-26 Ekim 2001, Șanliurfa, s: 985-992.

Bilgen, M. (1999). Arı Otunda (Phacelia tanacetifolia) Farklı Ekim Zamanlarının Çiçeklenme Özellikleri Üzerine Etkisi. Türkiye 3. Tarla Bitkileri Kongresi, 15-18 Kasım, Adana Cilt III, Çayır-Mera Yem Bitkileri ve Yemeklik Tane Baklagiller, 312-317.

Dağ, V. (2013). Farklı azot dozlarının arıotu (Phacelia tanacetifolia Bentham )'nda verim ve bazı tarımsal karakterlere etkisi. Yüzüncü Yıl Üniversitesi Fen Bilimleri Enstitüsü Tarla Bitkileri Anabilim Dalı, 48s.

Djordjevic, N., Dinic, B., Grubic, G., Vuckovic, S., \& Simic, A. (2005). The quality and chemical composition of Phacelia tanacetifolia Benth. and lucerne silages. Integrating efficient grassland farming and biodiversity. Proceedings of the $13^{\text {th }}$ International Occasional Symposium of the European Grassland Federation, Tartu, Estonia, 29-31 August, pp. 294-297.

Gilbert, L. (2003). Phacelia tanacetifolia: what we know about its suitability as an insectary plant and cover crop in the Mid-Atlantic region. Small 
Farm Success Project, Sustainable Agricultural Systems Lab, USDA, USA, 1.

Karadağ, Y., \& Büyükburç, U. (1999). Tokat Koșullarında Yetiștirilen Arıotunun (Phacelia tanacetifolia Benth.) Verim ve Adaptasyonu Üzerinde Bir Araștırma, GOÜ. Ziraat Fakültesi Dergisi, 16 (1):155-169.

Karadağ, Y., \& Büyükburç, U. (2001). Arıotunda (Phacelia tanacetifolia Benth.) Farklı Sıra Aralığının Ot ve Tohum Verimlerine Etkileri, Türkiye 4. Tarla Bitkileri Kongresi, 17-21 Eylül 2001, Tekirdağ. s: 143-148.

Karadağ, Y., \& Büyükburç, U. (2003). Tokat Koșullarında Arıotunun (Phacelia tanacetifolia Benth.) Yazlık Ekim Zamanı Üzerinde Araștırmalar. Ot Verimi İle İlgili Özellikler, A.Ü. Ziraat Fakültesi Tarım Bilimleri Dergisi, 9 (4), 435-439.

Kızılșimșek, M., \& Ateș, F. (2004). Kahramanmaraș Șartlarında Arıotunun (Phacelia tanacetifolia Bentham) Değișik Ekim Zamanlarındaki Çiçeklenme Seyri ve Arı Merası Olarak Değerlendirilmesi. KSÜ Fen ve Mühendislik Dergisi, 7(1), 96-103.

Kumova, U., \& Korkmaz, A. (2002). Arıcılık Açısından Arıotu (Phacelia tanacetifolia Bentham) Bitkisinin Önemi ve Bu Konuda Ülkemizde Yapılan Çalıșmalar. Uludağ Arıcılık Dergisi, 2002(1).

Lermi, A.G., \& Palta, Ș. (2014). The Effects of Different Sowing Dates of Fiddleneck (Phacelia tanacetifolia) During the Autumn and Spring Sowing Periods on the Forage Yield and Quality. Bartın Orman Fakültesi Dergisi2014, Cilt: 16, Sayı:23-24, 11-18.

Özkan, U., \& Benlioglu, B. (2015). Karyotype Analysis of the Fiddleneck (Phacelia tanacetifolia Benth.). Journal of Agricultural Science and Technology A, 336.

Sağlamtimur, T. \& Baytekin, H. (1993). Arıcılık İçin İdeal, Silaj Üretimine Uygun Bir Bitki: Arıotu, Teknik Arıcılık Dergisi, 40: 16-17.

Richards, I.R., Wallace, P.A., Turner, I.D.S. (1996). A comparison of six cover crop types in terms of nitrogen uptake and effect on response to nitrogen by a subsequent spring barley crop. J. Agric. Sci. Camb. 127, 441-449.
Stivers-Young, L. (1998). Growth, nitrogen accumulation, and weed suppression by fall cover crops following early harvest of vegetables. HortScience, 33(1), 60-63.

Tuncer, K. (2014). Farklı azot dozlarının arıotunun (Phacelia tanacetifolia Bentham) bitkisel özellikleri ve ot kalitesi üzerine etkisi / Influence of different nitrogen doses on plant properties and forage quality of Phacelia (Phacelia tanacetifolia Bentham). Bozok Üniversitesi / Fen Bilimleri Enstitüsü / Tarla Bitkileri Anabilim Dalı, S 51.

Wilczewski, E., Leman'czyk, G., Skinder, Z., \& Sadowski, C. (2006). Effect of nitrogen fertilization on the yielding and health status of selected nonpapilonaceous plant species grown in stubble intercrop. Electronic Journal of Polish Agricultural Universities, Vol. 9 No. 2.

Wilczewski, E., Skinder, Z., \& Szczepanek, M. (2008). Effect of the nitrogen dose on qualitative characters of green forage made of nonpapilionaceous plants grown in stubble intercrop. Acta Scientiarum Polonorum Agricultura. 7 (2): 133-141.

Wilczewski, E., Skinder, Z., \& Wydawnictwa, M. (2009). Influence of nitrogen fertilization on macronutrients content in the postharvest residue of non-papilionaceous plants cultivated in stubble intercrop. Acta Scientiarum Polonorum - Agricultura, 8 (2): 77-86.

Wyland, L.J., Jackson, L.E., Chaney, W.E., Klonsky, K., Koike, S.T., \& Kimple, B. (1996). Winter cover crops in a vegetable cropping system: Impacts on nitrate leaching, soil water, crop yield, pests and management costs. Agriculture, Ecosystems \& Environment, 59(1-2), 1-17.

Yılmaz, H. (2014). Eskișehir ekolojik koșullarında azotlu gübrelemenin arıtu (Phacelia tanacetifolia Bentham)'nun ot ve tohum verimi üzerine etkileri. Süleyman Demirel Üniversitesi / Fen Bilimleri Enstitüsü / Tarla Bitkileri Anabilim Dalı, S 54.

Yılmaz, H., \& Albayrak, S. (2017). Eskișehir Ekolojik Koșullarında Azotlu Gübrelemenin Arıotu (Phacelia tanacetifolia Benth.)'nun Ot Verimi Üzerine Etkileri. Journal of Field Crops Central Research Institute, 26(1), 93-103. 